(National Industrial Research Institute, Kyushu, Shukumachi, Tosu-shi, Saga, 841)

An infrared spectroscopic method was applied to the analysis of different types of organic sulfides in petroleum vacuum residue. Although sulfides have no characteristic infrared absorption band, their oxidized compounds, sulfones, show two strong absorptions associated with $\mathrm{S}=\mathrm{O}$ stretching vibration in the $(1300 \sim 1100) \mathrm{cm}^{-1}$ region. The vibrational frequencies of $\mathrm{S}=\mathrm{O}$ stretching modes are strongly dependent upon the chemical structure of the parent sulfides from which the sulfones are derived. The $\mathrm{S}=\mathrm{O}$ absorption bands of aromatic sulfones appear near $1150 \mathrm{~cm}^{-1}$ and $1300 \mathrm{~cm}^{-1}$. On the other hand, the corresponding $\mathrm{S}=\mathrm{O}$ absorptions for aliphatic sulfones occur at frequencies lower than those for aromatic sulfones and show a decrease in frequency with an increase in the number of carbon atom of alkyl group bonded with sulfur. The results obtained for these model compounds of sulfones were applied to the analysis of sulfides in the pyrolysis products of
Khafji vacuum residue. Cracked oils obtained from the residues showed strong absorption bands at (1115 $1120) \mathrm{cm}^{-1}$, (1145 1150) $\mathrm{cm}^{-1}$, and $(1298 \sim 1305) \mathrm{cm}^{-1}$ when oxidized with hydrogen peroxide and acetic acid, suggesting the presence of sulfur compounds with

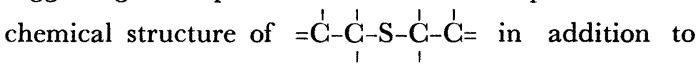
alkylarylsulfide, diarylsulfide or thiophene type sulfide. On the other hand, asphalt pitches showed two strong absorption bands at $(1145 \sim 1150) \mathrm{cm}^{-1}$ and $(1295 \sim 1300)$ $\mathrm{cm}^{-1}$ when oxidized, suggesting the presence of alkylarylsulfide, diarylsulfide or thiophene type sulfide.

(Received June 10, 1983)

\section{Keyword phrases}

analysis of organic sulfides in pyrolysis products $o$ Khafji vacuum residue; oxidation of sulfides to sulfones with hydrogen peroxide and acetic acid; infrared spectroscopy of sulfones.

\title{
水酸化ジルコニウム共沈法による陸水中のヒ亲 (III) 及びヒ素 $(\mathbf{V})$ の分別比色定量法
}

\author{
辻 治雄 ${ }^{\circledR,}$ 西村公男, 玉利祐三, 日下 譲* \\ (1983 年 8 月 15 日受理)
}

\begin{abstract}
陸水中に微量溶存するヒ素(III) 及びヒ素(V) を水酸化ジルコニウムを捕集戍として共沈濃縮し，濃 縮物よりテトラヒドロホウ酸ナトリウムを還元用として，七素(III) 及びヒ素(V) を順次七化水素に還 元気化し，それぞれをジェチルジチオカルバミン酸銀法で比色定量した. 水酸化ジルコニウム共沈時の 条件及びヒ素の分別還元気化時の諸条件について検討した。 ヒ素(III) 双はヒ素 (V) を $(0.5 〜 10.0) \mu \mathrm{g}$ 含む溶液 11 にジルコニウム $30 \mathrm{mg}$ を加え，フンモニア水で $\mathrm{pH} 9$ に調節し，傾斜法で上澄液を除 去し, 遠心分離する. 沈殿を塩酸に溶解し, ジルコニウムマスキングのための酒石酸を加え, テトラヒ ドロホウ酸ナトリウムにより，まず $\mathrm{pH} 6$ でヒ素(III) を，次いで約 $1 \mathrm{~N}$ 塩酸酸性としてヒ素(V) を還元気化し，順次発生してくるヒ化水素をジェチルジチオカルバミン酸銀ークロロホルム溶液中に分 別導入し，それぞれのヒ素を比色定量した．水酸化ジルコニウムによるヒ素の共沈濃縮は定量的であ り, 前記の濃度範囲における七素(III) 及びヒ素(V) の定量值の変動係数は約 $5 \%$ であった。この方 法によれば，陸水中に微量溶存する無機態ヒ素を特殊な装置を要せず，迅速に状態分析することができ る.
\end{abstract}

1 緒 言

陸水中に溶存する成分の起源及び水質と環境などの関

甲南大学理学部化学科 : 658 兵庫県神戸市東灘区岡本 8-9-1
係を明らかにすることは, 陸水の環境科学又は地球化学 において重要なことである。このためには，地質環境を 異にする地域ごとに採取した多数の試水について, 主成 分から微量成分に及ぶ多種類の溶存成分を同時分析し， それらの含有量を明らかにしておく必要がある．著者ら 
は，地下水などの陸水試料について，通常の化学分析法 とともに, 放射化分析法を適用して, 多元素同時分析を 行い, 32 成分群を分析し, その水質を明らかにしてき た ${ }^{1)}$ 。最近, このような水質科学に打いて, 微量溶存元 素の化学状態が注目され，それらの状態分析が重要にな ってきた2) 4).

一般に水質分析に打いては，多数試料，多種成分の分 析を行ら必要性から，溶存成分の分析法は，迅速かつ簡 便であり, 特殊な装置を要しない方法が要求される.

通常, 陸水中に溶存する七素の濃度は $10 \mathrm{ppb}$ 以下で あり，比色法又は原子吸光法で分析される．比色法の定 量限界は七素として $0.5 \mu \mathrm{g}$ 程度であるので, 数十 $\mathrm{ppb}$ までの特異的に高濃度の場合は直接分析できるが，それ 以下の濃度では水酸化鉄 (III) 飞よる共沈濃縮後8)99, ヨ ウ化カリウムと金属亜鉛又はテトラヒドロホウ酸ナトリ ウム (以後 STB と略記) で還元し，七化水素として揮 発分離し, ジェチルジチオカルバミン酸銀 (以後 $\mathrm{Ag}$ DDTC と略記）法で比色定量されることが多い，原子 吸光法では, その定量限界が数 $\mathrm{ng}$ であるので, 試料を そのまま比色法と同じ方法で還元し, 発生する七化水素 をコールドトラップに捕集し，分析される3)10)．しかし 七素は, 通常のアセチレン-空気炎では分析の困難な元 素の一つであるので, 無炎法11)12)，水素-空気炎又は水 素ーアルゴン炎法1013)で分析される．最近，七素の還元 気化法の改良が進み，STB による還元時の試水の $\mathrm{pH}$ を調節することにより，七素(III) 及びヒ素(V) を分別

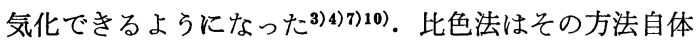
は簡便であるが，七素を前濃縮する必要があり，原子吸 光法は感度に優れているが，七化水素トラップや七素の 原子化に特殊な装置が要求される欠点がある.

本報では, 七素とともにアルミニウム, 銅, 鉄, マン ガン，亜鉛，セレン及びバナジウムなどを共沈濃縮でき る水酸化ジルコニウム濃縮法5)6) を用い，濃縮されたヒ 素をSTB によりヒ素(III) 及びヒ素(V) に分別気化分 離しそそれぞれを Ag-DDTC 法で比色定量した結果を 報告する．本法に上れば，七素の濃度範囲 $(0.5 \sim 10) \mu \mathrm{g} /$ 1 亿打いて，変動係数は約 $5 \%$ であり，20 種の試料を 約 3 時間で分析することができた。

\section{2 試薬，分析試料及び装置}

\section{1 試 薬}

試薬は入手できる限り, 特級又は精密分析用試薬を用 い，純水には RO pure+NANO pure 純水装置 (Barnsted 社製) で得たイオン交換水を，更に石英蒸留器で再 蒸留したものを用いた。

七素 $(\mathrm{III})$ 標準原夜 $\{1 \mathrm{mg} \mathrm{As}(\mathrm{III}) / \mathrm{ml}\}$ : 分析用三酸
化ヒ素 (Merck 社製) $0.1320 \mathrm{~g}$ を水酸化ナトリウム溶液 (1 N) $10 \mathrm{ml}$ に溶解し, 水でうすめ, 塩酸 $(2 \mathrm{~N})$ で微 酸性として, 水で $100 \mathrm{ml}$ とした．実験に際して，この 原液を適宜希彩して用いた。

七素 $(\mathrm{V})$ 標準溶液 $\{100 \mu \mathrm{g} \mathrm{As}(\mathrm{V}) / \mathrm{ml}\}$ : 上記の七素 標準原液 $10 \mathrm{ml}$ に濃硝酸 $5 \mathrm{ml}$ と $6 \mathrm{~N}$ 塩酸 $1 \mathrm{ml}$ を加 えて，水浴上で蒸発乾固した後，水に溶解して $100 \mathrm{ml}$ とした，実験に際しては，適宜希釈して用いた。

オキシ塩化ジルコニウム溶液 $(10 \mathrm{mg} \mathrm{Zr} / \mathrm{ml})$ : 特級 オキシ塩化ジルコニウム八水和物（和光純薬製） $3.53 \mathrm{~g}$ を水に溶解し $100 \mathrm{ml}$ とした。

STB 溶液 $(4 \mathrm{w} / \mathrm{v} \%)$ : 化学用 STB (和光純薬製) 0.83 $\mathrm{g}$ を水に溶解して $20 \mathrm{ml}$ とした。この溶液は実験の都 度調製した。

$\mathrm{pH} 6$ トリス䌅衝溶液 $\left.{ }^{3}\right)$ ：トリス（ハイドロオキシメ チル)ーフミノメタン (P-L Biochemicals Inc. 製) 7.57 $\mathrm{g}$ を $6 \mathrm{~N}$ 塩酸 $10.3 \mathrm{ml}$ に溶解し, 水で $25 \mathrm{ml}$ とした。 この溶液 $1 \mathrm{ml}$ を水で $50 \mathrm{ml}$ に希釈して用いた.

Clark-Lubs 緩衝溶液14)：0.2 M に調製した塩化カリ ウム溶液, フタル酸水素カリウム溶液, リン酸二水素カ リウム溶液, 塩酸及び水酸化ナトリウム溶液を適宜組み 合わせ，それぞれを混合して種々の $\mathrm{pH}$ の髣衝溶液を調 製した。

$\mathrm{Ag}-\mathrm{DDTC} ク ロ ロ ホ ル ム$ 溶液 $(0.25 \mathrm{w} / \mathrm{v} \%): \mathrm{Ag}-$ DDTC（同仁化学製） $0.25 \mathrm{~g}$ とブルシン二水和物（和光 純薬製) $0.05 \mathrm{~g}$ をクロロホルムに溶解し $100 \mathrm{ml}$ とし た。

その外, 塩酸, 硝酸, アンモ二フ水, クロロホルムな どは，蒸留法により精製して用いた。

\section{2 分析試料}

人工海水試料 ${ }^{15)}$ : 主成分濃度を標準海水のそれに類似 させたものを調製した。

地下水試料 (No. 1) : 表六甲沖積層地下水の代表試料 として, 甲南大学構内の 浅井戸（深さ $3 \mathrm{~m}$ ) より採取 した。

地下水試料 (No. 2) : 六甲山南簏の活断層線上に位置 すると考元られる神戸市灘区鶴甲地区の湧水を採取し た.

池水試料：神戸市の上水道に用いられる千刈水源池に おいて, バンドーン採水器により, 表層より深度 $31 \mathrm{~m}$ ま での試料を哚度別に採取した。

温泉水試料：神戸市有馬温泉花乃坋泉源よりの湧水を 採取した。

上記のらち天然水試料はいずれも，採水後直ちに 0.45 $\mu \mathrm{m}$ のミリポフフィルターで沪過し， $0.05 \mathrm{~N}$ 塩酸酸性 として保存し，24 時間以内に分析した。

\section{3 装}

分光光度計：日立 100-10 型分光光度計

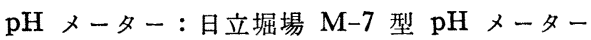
遠心分離機：久保田遠心分離機 $\mathrm{K}-12 \mathrm{~A} 2$ 型 七化水素発生装置: 日本工業規格, 工場排水試験方法 （JIS K 0102）に定められている七化水素発生装置の一 部を改造したものをFig. 1 に示した. 


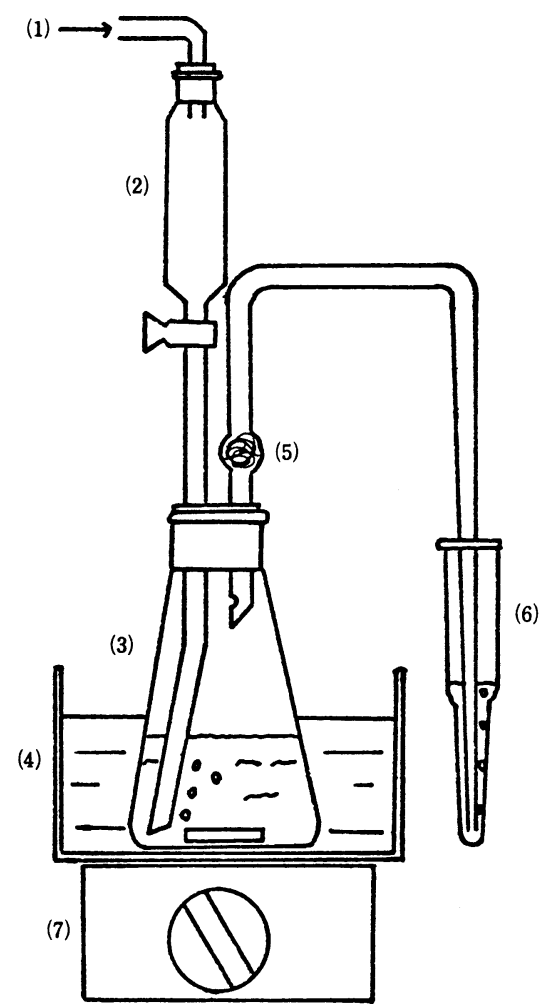

Fig. 1 Apparatus for generation and collection of arsine

(1) Argon; (2) Funnel; (3) Reaction vessel (100 ml); (4) Water bath $\left(25^{\circ} \mathrm{C}\right)$; (5) Glass wool; (6) Absorbent tube; (7) Magnetic stirrer

\section{3 実験及び結果}

\section{1 操 作}

3.1 .1 水酸化ジルコニウム共沈法 試水 11 亿素 として $(0.5 \sim 10) \mu \mathrm{g}$ を含む\}にオキシ塩化ジルコニウム 溶液 $3 \mathrm{ml}$ とメタクレン゙ールパープル指示薬数滴を加 え, かき混ぜながら $10 \%$ アンモニア水を指示薬が変色 するまで加兄 (pH 9), 水酸化ジルコニウムを沈殿させ る. 沈殿が凝集沈降するまで放置し，上澄液を捨て，250 $\mathrm{ml}$ の遠沈管に移し, $3000 \mathrm{rpm}$ で 20 分間遠心分離する. 得られた沈殿を $6 \mathrm{~N}$ 塩酸 $1 \mathrm{ml}$ に溶解し, 酒石酸溶液 $(25 \mathrm{w} / \mathrm{v} \%) 5 \mathrm{ml}$ を加え, アンモニア水で中和してほぼ 中性とし, 更に水を加えて全量を $50 \mathrm{ml}$ とする.

\subsection{2 七素(III) 及びヒ素(V) の分別比色定量法}

試料液 $50 \mathrm{ml}$ \{七素として $(0.5 \sim 10) \mu \mathrm{g}$ を含む\} をと化 水素発生瓶に採り, トリス緩衝液 $2 \mathrm{ml}$ を加える（pH 6). $25^{\circ} \mathrm{C}$ の水浴中で STB 溶液 $3 \mathrm{ml}$ を滴下漏斗より
滴下し，直ちにアルゴンを $(60 \sim 100) \mathrm{ml} / \mathrm{min}$ の流速で 20 分間通気し，発生する 七化水素を吸収管中の $\mathrm{Ag}-$ DDTC 溶液 $5 \mathrm{ml}$ に捕集する. この操作でヒ素(III) の みが還元，分離される．この吸収液の吸光度を波長 540 $\mathrm{nm}$ で測定する. 次いでこの発生瓶に $6 \mathrm{~N}$ 塩酸 $5 \mathrm{ml}$ を 加光, STB 溶液 $3 \mathrm{ml}$ を滴下し, 前と同様アルゴンを 15 分間通気し, 七素 $(\mathrm{V})$ を七化水素として分離し, 吸 収液に捕集してその吸光度を測定する.

ジルコニウム共沈法と組み合わせてこの方法を適用す るときは，ジルコニウムによりヒ素の還元気化が妨害さ れるので, 検量線作成時の標準試料列にもジルコニウム を同濃度添加し，酒石酸溶液をマスクキング剤として添 加する必要がある.

\section{2 七素(III) 及びヒ素(V) の分別定量法の検討}

3.2.1 ヒ化水素発生時の pH の影響 $\mathrm{pH} \mathrm{0} \mathrm{9} \mathrm{の}$ 範用の諸種の $\mathrm{pH}$ の Clark-Lubs 緩衝液 $50 \mathrm{ml}$ に, ヒ 素(III) 又はヒ素(V) を $10 \mu \mathrm{g}$ 量添加し，前記した方法 により，七素(III) 及びヒ素(V) を定量し， $\mathrm{pH}$ とヒ素 回収率の関係を求めた. 結果は Fig. 2 に示すように,

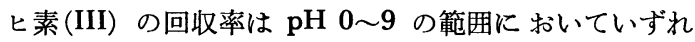

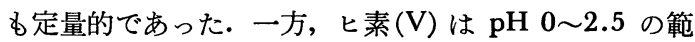
囲では定量的に回収されるが，pH 3 以上から回収率は 低下し，pH 6 以上では回収されなかった.これらの結 果より本法では，まず pH 6 としてヒ素(III) のみを,

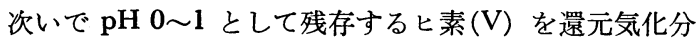
離できることが明らかとなった。

3.2.2 STB 添加量の影響 七素(III) 又はヒ素(V) の $10 \mu \mathrm{g}$ 量を, 前者は $\mathrm{pH} 6$, 後者は $1 \mathrm{~N}$ 塩酸酸性の 溶液とし，これに STB 溶液の 添加量を $(0.2 \sim 10) \mathrm{ml}$ の範囲で変化させ, STB 添加量と七素回収率の関係を 求めた. その結果, 七素(III) 及びヒ素(V) はいずれも,

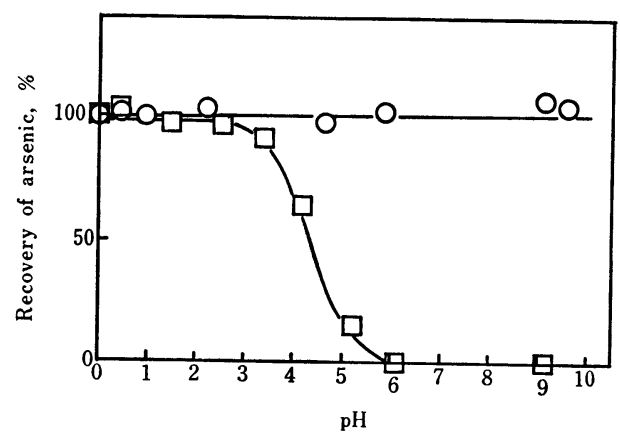

Fig. 2 Effect of $\mathrm{pH}$ on arsine generation $O$ Arsenic(III) : 10 $\mu$ g; $\square$ Arsenic(V) $: 10 \mu \mathrm{g}$ 
$\mathrm{STB}$ 溶液の $1 \mathrm{ml}$ 以上の添加により定量的に回収され た. 従って本法では, STB 溶液量をいずれも $3 \mathrm{ml}$ と した.

3.2.3 ヒ化水素発生時の反応時間一般に STBを 用いる七素の七化水素への還元反応に要する時間は, 他 の還元剤を用いる場合に比べ短いとされている. 又, 反 応溶液の $\mathrm{pH}$ によっても反応時間を異にする.そこで, pH 6 の溶液中の七素(III) 及び $1 \mathrm{~N}$ 塩酸溶液中の七素 (V) の STB による還元時の反応時間を $(2 \sim 30)$ 分の 範囲で変化させ，反応時間とヒ素回収率の 関係を求め た.この結果, 七素(III) は 15 分で, 七素(V) は5 分 で定量的に還元気化されることが明らかとなった．本法 では, 還元時の反応時間を七素(III) については 20 分, ヒ素(V) については 15 分とした.

3.2.4 共有するジルコニウムのマスキングジルコ ニウム共沈法により得た濃縮液について, 酒石酸マスキ ング剤を添加することなく,本法を適用したところ, ヒ素 (III) は約 $80 \%$ の回収率であり, 七素(V) は全く還元 気化されず，共存するジルュニウムによるヒ素の還元気 化に対する妨害が顕著であった．このジルコニウムによ る妨害をマスキングするため，酒石酸をマスキング㨈と して選び，七素(III) 又はヒ素(V) の $10 \mu \mathrm{g}$ 量及びジル コニウム $30 \mathrm{mg}$ を含む溶液に酒石酸 $(25 \%$ 溶液)を 0 〜 $2.5 \mathrm{~g}$ の範囲で加えた後 $\mathrm{pH}$ を調製し, 本法により回収 実験を行った. 結果を Fig. 3 に示す. 七素(III) は, 酒石酸 $0.1 \mathrm{~g}$ の添加で定量的回収率が得られた。しか しヒ素 $(\mathrm{V})$ は，いずれの酒石酸添加量においても定量的 回収率は得られなかったが，酒石酸添加量 $0.5 \mathrm{~g}$ 以上の 場合, 常に $85 \%$ の回収率を示し, 標準試料にもジルコ ニウムを添加し，分析試料と同様の処理をすれば，七素 (V) の定量が可能であることが明らかとなった.

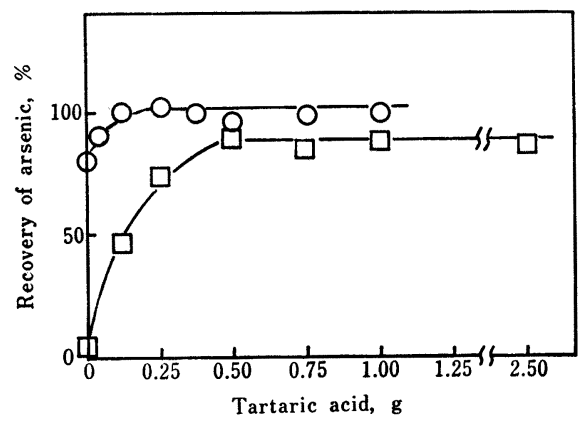

Fig. 3 Masking effect of tartaric acid for zirconium on arsine generation

O Arsenic(III) $: 10 \mu \mathrm{g} ; \square$ Arsenic(V) $: 10 \mu \mathrm{g}$

\section{3 水酸化ジルコニゥム共沈法の検討}

3.3.1 ジルコニウム添加量の影響 純水 11 に, ヒ 素(III) 又は七素(V) を $10 \mu \mathrm{g}$ 量添加し, これにジルコ ニウムを $(2 \sim 30) \mathrm{mg}$ の範囲で加えて共沈濃縮し, ジル コニウム量とヒ素の回収率の関係を求めた. この結果, ヒ素(III) 及びヒ素(V) のいずれの場合も, ジルュニウ 么量 $10 \mathrm{mg}$ 以上で定量的に共沈濃縮されることが明ら かとなった．実際の試料への適用に際しては, 他のイオ ン種の存在も考慮して, ジルュニウム量を $30 \mathrm{mg}$ とす ることにした.

3.3.2 共沈時の $\mathbf{p H}$ の選定 七素(III) 及びヒ素 (V) を, 水酸化ジルコニウム共沈するときの $\mathrm{pH}$ を 6 １1 の範囲で変化させ, $\mathrm{pH}$ と七素回収率の関係を求 めた結果, 実験した $\mathrm{pH}$ の範囲内では, いずれの $\mathrm{pH} に$ おいても七素は定量的に回収された. 本法では, 沈殿の 凝集が早く, 溶液との分離が最も容易な $\mathrm{pH} 9$ を, 共 沈時の $\mathrm{pH}$ に定めた.

\section{4 標準添加法による本法の適用性の検討}

純水, 人工海水及び地下水試料 (No. 1) を試料とし, 標準添加法を行って, 本法の適用性を検討し, その結果 を Table 1 に示した. この方法で求めたヒ素(III) 及 びヒ素(V) の回収率は, いずれの試料についても満足す べきものであり, 本法は $0.5 \mu \mathrm{g} / 1$ 以上の七素を含む試 料に適用できることが明らかになった.

\section{4 陸水試料への適用}

池水, 地下水及び温泉水試料に本法を適用した結果を Table 2 に示した. 浅層地下水, 鶴甲湧水及び 池水表 層から中層にかけての試水については, 七素(V) のみが 定量され，これらの水は酸化状態にあることが認められ る. 一方, 池水底層より採取したものは，七素(III) の みが定量され，採水時に 測定した酸化還元電位の 低值 (300 mV 以下) と合わせて, 底層水は停滞状態にあり, 還元性の環境にあることを示している. 深度 $500 \mathrm{~m}$ か らの湧水である有馬温泉水は, 七素(III) 含有量がヒ素 （V）より高值であり，嫌気性の試料水であると考えられ る. 又, 活断層よりの涌水と考えられる鶴甲涌水が, 他 の試料と比べ約 100 倍の高い七素含有量を示すことは, 地球化学的に興味深い. Table 2 に示した試料のらち, 池水底層部（深度 $29 \mathrm{~m}$ 以上）のものは, 中層部より浅 い層にかけての試料に比べ溶存成分濃度が高く, 特に 鉄 (II) $(96 \mathrm{mg} / 1)$ 及び マンガン $(12 \mathrm{mg} / \mathrm{l})$ に富む. 又, 含鉄・ナトリウム一塩化物強塩泉である有馬温泉水で は, 蒸発残留物は $65 \mathrm{~g} / \mathrm{kg}$ にb達し, 含有する鉄(II) 
Table 1 Recovery of arsenic(III) and arsenic(V) by the coprecipitation method with zirconium hydroxide

\begin{tabular}{|c|c|c|c|c|c|c|}
\hline \multirow{2}{*}{ Sample } & \multicolumn{3}{|c|}{ As(III) } & \multicolumn{3}{|c|}{$\operatorname{As}(V)$} \\
\hline & $\begin{array}{l}\text { Added } \\
(\mu g)\end{array}$ & $\begin{array}{l}\text { Found } \\
(\mu \mathrm{g})\end{array}$ & $\begin{array}{l}\text { Recovery } \\
(\%)\end{array}$ & $\begin{array}{l}\text { Added } \\
(\mu \mathrm{g})\end{array}$ & $\begin{array}{c}\text { Found } \\
(\mu \mathrm{g})\end{array}$ & $\begin{array}{c}\text { Recovery } \\
(\%)\end{array}$ \\
\hline \multirow[t]{3}{*}{ High-purity water $\dagger$} & 2.0 & $1.8 \pm 0.1$ & $90 \pm 6.5$ & 2.0 & $1.8 \pm 0.2$ & $90 \pm 7.9$ \\
\hline & 5.0 & $4.7 \pm 0.3$ & $94 \pm 5.1$ & 5.0 & $5.0 \pm 0.3$ & $100 \pm 6.6$ \\
\hline & 10.0 & $9.5 \pm 0.2$ & $95 \pm 1.9$ & 10.0 & $9.6 \pm 0.4$ & $96 \pm 4.4$ \\
\hline \multirow[t]{4}{*}{ Artificial sea-water } & 0 & N. D. †t† & & 0 & 0.8 & \\
\hline & 2.0 & 2.0 & 100 & 2.0 & 2.7 & 95 \\
\hline & 5.0 & 4.8 & 96 & 5.0 & 5.4 & 92 \\
\hline & 10.0 & 9.8 & 98 & 10.0 & 10.0 & 92 \\
\hline \multirow[t]{4}{*}{ Groundwater No. $11^{\dagger}$} & 0 & N. D. & & 0 & 0.5 & \\
\hline & 2.0 & 2.0 & 100 & 2.0 & 2.5 & 100 \\
\hline & 5.0 & 4.9 & 98 & 5.0 & 5.4 & 98 \\
\hline & 10.0 & 9.9 & 99 & 10.0 & 10.0 & 95 \\
\hline
\end{tabular}

$\dagger$ Water obtained by distilling double-deionized water, mean values and standard deviations for 5 determinations; $\dagger \dagger$ Groundwater collected from a shallow well in Konan Univ.; t†† Not detected.

Table 2 Determination of arsenic in groundwater

\begin{tabular}{lccc}
\hline Sample & $\begin{array}{c}\text { Water depth } \\
(\mathrm{m})\end{array}$ & $\begin{array}{c}\text { As(III) } \\
(\mathrm{ppb})\end{array}$ & $\begin{array}{c}\text { As(V) } \\
(\mathrm{ppb})\end{array}$ \\
\hline Pond water $^{\mathrm{a})}$ & 0 & N. D. ${ }^{\theta)}$ & 0.6 \\
& 6 & N. D. & 0.7 \\
& 12 & N. D. & 0.7 \\
& 18 & N. D. & 0.7 \\
& 24 & N. D. & 0.5 \\
& 27 & N. D. & 0.7 \\
& 29 & N. D. & N. D. \\
Groundwater No. 1 & 30 & 0.5 & N. D. \\
Groundwater No. 2 b) $^{\text {b) }}$ & 31 & 0.5 & N. D. \\
Hot spring water & & N. D. & 0.7 \\
\hline
\end{tabular}

a) Pond water collected from Sengari reservoir in Kobe; b) Groundwater collected from Tsurukabuto in Kobe; c) Hot spring water collected from Arima in Kobe; d) Analytical value determined without coprecipitation procedures; e) Not detected.

$(87 \mathrm{mg} / \mathrm{l})$ 及び マンガン $(61 \mathrm{mg} / \mathrm{l})$ の濃度は極めて高 い.これらの試料については本法以外に，溶存する鉄 (II) を硝酸で酸化後, この鉄(III) を担体としてヒ素を 共沈濃縮し，本法の STB 還元気化法でヒ素(V) を定 量した. この結果, Table 2 で示したヒ素(III) 及びと 素(V) 定量值の 合計量に 相当する七素定量值が得られ た.これらの結果から, 本法は, 地下水などに溶存する ことの多い鉄及びマンガンなど水酸化物を生成する溶存 種により妨害されないことも明らかになった.

\section{5 結語}

陸水中に微量溶存する七素を, 水酸化ジルコニウムに 共沈濃縮し，STBによりヒ素(III) 及びヒ素(V) を逐 次還元気化し，それぞれを Ag-DDTG 比色法で分別定 量する七素の微量溶存状態分析法が確立できた. 本法は
特殊な装置が要求されず，簡便かつ精度よく分析できる ので, 環境あるいは地球化学的調查の分析法として利用 できる. 又，水酸化ジルコニウム共沈法は，捕集㓮とな るジルコニウムが環境試料中にはまれな元素であり，鉄 その他の捕集剂に比べて高純度物が入手しやすく，捕集 剤による分析元素の污染が生じ難い利点がある.この方 法によれば，七素以外にも酸素酸として水中に微量溶存 するセレン及びバナジウムなどを共沈濃縮できる可能性 があり，酸化状態を異にする化学種を状態分析できるの で，水試料についての前濃縮法として有用である。な お, ジルュニウムは中性子により放射化され難い元素で あるので, 濃縮物を中性子放射化分析することにより, 多元素同時分析法への発展が期待できる.

\section{交献}

1) Y. Kusaka, H. Tsuji, Y. Fujimoto, K. Ishida, Y. Fukui, T. Mamuro, T. Matsunami, A. Mizohata, S. Hirai : J. Radioanal. Chem., 71, 7 (1982).

2) 由井収, 平木敬三, 西川泰治, 重松恒信 : 分 化, 26, 91 (1977).

3) M. O. Andreae : Anal. Chem., 49, 820 (1977).

4) R. S. Braman, C. C. Foreback : Science, 182, 1247 (1973).

5) 佐藤 彰 : “高温师原子吸光分析の実際”, p. 15 (1981)，（講談社).

6) 鵧沢 惇, 吉村 担: 分化, 32, 115 (1983).

7) A. G. Howard, M. H. Arbab-Zavar : Analyst (London), 105, 338 (1980).

8）金子恵美子：分化, 27，250 (1978)

9）日本水道協会：上水試験法 (1978).

10) J. Agget, A. G. Aspell : Analyst (London), 101, 341 (1976).

11) 柳 勝美: 分化, 29, 194 (1980).

12）小田中芳次, 俣野修身, 後藤真康 : 分化, 28, 
517 (1979).

13）山本勇麓, 熊丸尚宏, 林 康久, 鎌田俊彦：分 化，22，876 (1973).

14）日本分析化学会編：“分析化学データブック”, 改 訂二版，p. 30 (1973)，（丸善).

15）気象庁編：“海洋観測指針”, p. 146 (1970)，（日 本海洋学会).

$$
\stackrel{s}{s}
$$

Sequential spectrophotometric determination of inorganic arsenic(III) and arsenic(V) species in groundwaters by means of coprecipitation with zirconium hydroxide. Haruo TsujI, Kimio NishIMURA, Yuzo TAMARI, and Yuzuru KuSAKA. (Department of Chemistry, Faculty of Science, Konan University, 8-9-1, Okamoto, Higashinada-ku, Kobe-shi, Hyogo, 658)

Arsenic(III) and arsenic(V) in groundwaters at ppb levels are determined by a spectrophotometric method with silver diethyldithiocarbamate (SDDC), after preconcentration by means of coprecipitation with zirconium hydroxide, and sequential generation of arsine with sodium tetrahydroborate by $\mathrm{pH}$ adjustment of sample solution. Three milli liters of $3.53 \%$ zirconium oxychloride solution ( $30 \mathrm{mg}$ as $\mathrm{Zr}$ ) is added to $1000 \mathrm{ml}$ of sample solution containing $(0.5 \sim 10) \mu \mathrm{g}$ of arsenic, then the solution is adjusted to $\mathrm{pH} 9$ with aqueous ammonia. After standing for a while, the precipitate is collected by centrifuging, dissolved in $1 \mathrm{ml}$ of $6 \mathrm{~N}$ hydrochloric acid solution, and transferred to a reaction vessel. Then $5 \mathrm{ml}$ of $25 \%$ tartaric acid solution is added, and the solution is adjusted to $\mathrm{pH} 6$ with aqueous ammonia. The solution is diluted to about 50 $\mathrm{ml}$ with water, and $2 \mathrm{ml}$ of Tris buffer solution is addeed to the vessel. Into the reaction vessel, $3 \mathrm{ml}$ of $4 \%$ sodium tetrahydroborate solution is injected from a funnel, and argon is bubbled at the flow-rate of $(60 \sim$ 100) $\mathrm{ml} \mathrm{min}^{-1}$ for $20 \mathrm{~min}$. Arsine generated from arsenic(III) is trapped in a SDDC solution(1). Hence $5 \mathrm{ml}$ of $6 \mathrm{~N}$ hydrochloric acid is added to the vessel to bring the $\mathrm{pH}$ of the solution to $0 \sim 1$. Three milliliters of $4 \%$ sodium tetrahydroborate solution is injected and argon is bubbled for $15 \mathrm{~min}$ to generate arsine from arsenic $(\mathrm{V})$. Arsine is trapped in another fresh SDDG solution (2). The concentrations of arsenic in both SDDC solutions (1) and (2) are determined by spectrophotometry at $540 \mathrm{~nm}$. The recoveries of arsenic (III) and arsenic (V) are quantitative and thier coefficients of variation are about $5 \%$ ranging $(2.0 \sim$ $10.0) \mu \mathrm{g}$ of arsenic, and the detection limit of arsenic is about $0.5 \mu \mathrm{g}$. This method is rapid and convenient for the determination of trace amounts of inorganic arsenic species in groundwaters.

(Received August 15, 1983)

\section{Keyword phrases}

spectrophotometric determination of arsenic(III) and $\operatorname{arsenic}(\mathrm{V})$ ingroundwater with silver diethyldithiocarbamate; coprecipitation with zirconium hydroxide; sequential generation of arsine with sodium tetrahydroborate.

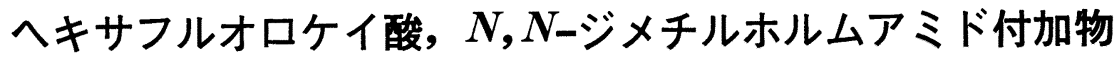 によるモリブデンの非水電導度滴定
}

\author{
吉村 長蔵, 藤野 隆由 ${ }^{\circledR *}$ \\ (1983 年 6 月 22 日受理)
}

\begin{abstract}
ヘキサフルオロケイ酸と $N, N$-ジメチルホルムフミド（DMF）との固体付加物を標準試薬として用 い, モリブデンの非水電導度滴定を検討した。 DMF 中における滴定曲線には，モリブデン(VI) : $\mathrm{H}_{2} \mathrm{SiF}_{6}=2: 1$ と $1: 1$ のイオン対生成反応と考えられる結合比に明り上うな屈折点が得られ，モリブ デン(VI) の直接滴定が 可能である. 併せて, 吸光光度法でも $2: 1$ の結合比の反応点が得られた. 又，実際分析への応用として二硫化モリブデンを含む潤滑油を対象にして，電導度滴定を行った結果， 迅速にモリブデンの定量ができた.
\end{abstract}

